\title{
造形における図法幾何学, そして図学
}

神山明 Akira KAMIYAMA

本稿に書くべきことは, 今後の図法幾何学についてで あろうが，「今図学は必要なのか」という問題にやはり 触れざるを得ない，また筆者はこれら問題についていま だ明確な考えを持てずにいるので，日頃感じている雑感 を含めて記するがお許しいただきたい，

\section{1.「図学は必要か」一「美術教育」シンポジウ ムで考えたこと}

先般「美術教育」に関するシンポジウムに出席した が，そこでは小中高等学校の教科としての「美術」時間 の削減問題が議論された。行政側からは，美術の時間の 削減あるいは廃止の意見が教育審議会等の公的な場でも 強いという危機的状況が語られ，現場の美術教師からは 経験を背景とした美術教育の重要性と意義が語られ，そ の議論は平行線をたどる結果となった。 それは，まるで 現在の図学を取り巻く状況と全く同じではないかと感じ た.「美術」と「図学」を入れ替えれば，同じ構造が成 り立つと思われたのである，行政側からは，「美術」が

「情操教育」に必須であるという従来からの論点では, 「美術」という教科の生き残りははかれないという指摘 がなされた。「情操教育」という視点だけでは，「芸術」 という科目でもいいし「音楽」があればよいという結論 も導かれる可能性もある。「美術」はなぜ必要かという 問には答えていないからである，筆者は，図学の重要性 と必要性をもちろん感じ，現在の図学不要の風潮に反対 するものであるが，その反対の立脚点の弱さを指摘され ているようにその議論を聞いたのである．現場の教員 は，体験を踏まえての実感を込めて「美術」の素晴らし さを熱っほく語るが，ある地点を通り過ぎた体験談には 「信仰」という言葉がおもわず浮かんでしまった。

\section{2.「学問」と「教育」をすること, あるいは「研} 究者」と「教員」であることの難しさ

「図法幾何学」の新たな確立は，学問としての現代性 を問うものであろうが，同時に図学という授業科目を削
減消滅させないためという，極めて現実的な問題を問う ものでる．その二つの論点は，かたやその純粋性におい て，かたや現実性において両極の性質のものである，研 究者であるが教員でもあるという，あまりに自明でいま さら論じることの恥ずかしいような本質的問題が，やは り問題なのである（筆者が実際に悩んでいることは，有 り体に言えばそこである．望めば死ぬまで研究者あるい は作家でいられるが，科目が無くなればその時点で教育 者ではいられない).

そこで四法幾何学について考えると，今後も「図学」 という科目があるとしたら（名称は変化するかもしれな いが），第三者にも答えられるその有効性は何か，とい う点がもっとも重要であろう．有効性を語らなければ, なぜ罒学が必要かという問には答えられない。そしてそ の有効性の中で「図法幾何学」が何をなし得るかという 事が重要である.「図法幾何学」の有效性を先に考えて いくと，無理な自己正当化に陥る危険性を感じざるを得 ない，完成された「図法幾何学」の体系の美しさに筆者 は感動を覚えるものであるが，それを語る場を間違える と，聞かされる側は「信仰」としか思えないかもしれな い.

\section{3. 工学系と造形系との「図学」の遣い}

筆者が自分のための資料や授業のテキストとして使う ものは, 工学系の方々の書かれたものが多い，そこで常 に感じることは，造形の分野の学生にその内容のどこま でを教えるかという事である．作図や形態の基本的理解 と各種投影法等を基本とし，造形系としての授業で不足 すると思われる内容を追加し，課題を設けている.

そこでより造形に関わる内容を扱おうとすると，投影 を中心とする図法幾何学の時間は不足することになる. また投影を中心とした内容を確実に行おうとすれば，授 業は「図法幾何学」そのものに近づいてしまう.「図学」 の有効性を考える以前に「図法幾何学」だけの授業にな りかねない，授業では工学系の教科書を「利用させても 
らっている」というのが実感である，その中で造形系の 各教員は，個々に造形に必要と思われる内容を工夫しな がら授業を行っていると思われる，その際，造形系の図 学を担当する教員同士の, 授業内容の連携がさらに必要 であろう。造形系は図学に関わる方々全体の中では少数 かもしれないが, それならなおさら授業内容の工夫も共 有できるであろう。造形における「図法幾何学」の位置 づけはその中で明確になるかもしれない.

しかし，各自が工夫している造形を背景とした授業内 容は，基本的に「個人の出題する造形的側面を持つ課 題」になりがちであることが，本質的な問題でもある.

「図学」あるいは「図法幾何学」は学問としての大系を 持つのに対して,「造形的課題」は極めて個人的㑡面を 持つものである，その部分が多くなればなるほど，授業 は「図学」という一般性のある学問から離れてしまう.

筆者の場合授業の中で行っているのは「神山の課題」に なるのだろうが，「神山の課題」に他者を納得させるだ けの普遍性を持たせるのは，至難のわざであろう.

また「造形系」といっても，現実には「造形」専攻の 学生はおらず,「絵画」「彫刻」「工芸」「デザイン」「芸 術学」その他, 様々な学生が「造形系」として存在して いる. その各分野において,「図学」に求める内容は自 ずから異なるであろう。「造形」なのであるから，それ らの差異は小さいと見ることもできようが, 実際にはそ の造形の解釈はとりわけ近年は異なっているであろう.

「絵画の何に」あるいは「デザインの何に」有効かとい うことを, 共通のものとして提示することは, 極めて困 難である. 基本的な造形力を背景とした思考や表現とい う素朴な観点からは，今日の造形の他分野をくくる事は できない.そこで「造形一般」に有効性のある「図学」 を考えると，より本質的な図と形の普遍的な内容に向か わざるを得ない. そうすると即効性のある内容とは遠く なり, 有効性のある図学とは遠ざかってしまうのであ る.

\section{4.普遄性のある「造形の図学」のありかた}

このように今日の図学は, 有効性を持たせようと思え ば，専門分野別あるいは個人的なものになり，授業科目 として求められる一般的な有効性とは相反する問題があ る.しかし，筆者は解答を得ていないのであるが，また 「信仰」であってはならないのだが，なお，「造形のた
めの図学」の一般的な形があり, なお有効性のあるもの はあるはずだ，というのが筆者の考えである.

問題は緊急のことであり, 悠長な事を言っている場合 では無いのかもしれないが，それは「より本質的なもの に戻る」というのが，ひとつの考えなのではないだろう か.

モンジュの「図法幾何学」から始まったのが現在の 「図学」の基本なのだろう。では何をモンジュは「図法 幾何学」として体系化したのだろうか.「石切術の図法」

「画家の透視図」など，それまでにあった形や図に関わ る諸分野の技法や思想を体系化したのではなかったろう か. その後,「図法幾何学」は発展し, 日本においては 工学系の大学や師範学校で基礎科目となり, 美術系の学 校では透視図の基礎として教育されていく，その工学の ための基礎あるいは絵画のための基礎という立場は, 現 在もある「製図のための基礎」あるいは「造形のための 基礎」という, 専門に対しての弱い立場に続くものでは ないだろうか. 本来困法幾何学は何を解決したのかを考 えてみると, とりわけ造形の分野の場合, 絵画や図一般 における空間の表現や, 立体の理論的な理解など, 普遍 的な造形の基本に関わるものであることはあきらかであ る. その基本的な問題を, どのように提示するかが重要 であろう。そこでは図法幾何学の基本を踏まえることが 必要であろう。しかし,「図法幾何学」を前面に出す必 要はないかもしれない. 現在「図法幾何学」それ自体は 「有効性」を訴え得るものではないだろう。また，コン ピュータや CAD,CGの登場への対応に重点を置いて は,「有効性」の確立が難しいと思われる．まず造形の 立場での普遍的な形体や表示の問題を提示し, それを 「図法幾何学」を中心として考えることが重要であろ う.そしてさらに，前述した「個々の教員の工夫による 課題」を，個人的な一回性のものでない広く図学に関わ る人に共有しうる普遍的なものに高められれば，より望 ましいのではないだろうか.

\section{かみやま あきら}

彫刻家, 東海大学教養学部芸術学科教授 1953年生まれ，1977年東京芸術大学大学院修了

個展, グループ展等で作品を発表

図学, 造形理論, 造形演習等の授業を担当 